\section{Molecular Characterization of Chinese Grape Landraces (Vitis L.) Using Microsatellite DNA Markers}

\author{
Beibei $\mathbf{L i}^{1}$ \\ Zhengzhou Fruit Research Institute, Chinese Academy of Agricultural \\ Sciences, 450009, Zhengzhou, Henan Province, People's Republic of \\ China; and College of Forestry, Henan University of Science and \\ Technology, 471003, Luoyang, Henan Province, People's Republic of China
}

Jianfu Jiang ${ }^{1}$, Xiucai Fan, Ying Zhang, and Haisheng Sun

Zhengzhou Fruit Research Institute, Chinese Academy of Agricultural Sciences, 450009, Zhengzhou, Henan Province, People's Republic of China

\section{Guohai Zhang}

College of Forestry, Henan University of Science and Technology, 471003, Luoyang, Henan Province, People's Republic of China

\section{Chonghuai Liu ${ }^{2}$ \\ Zhengzhou Fruit Research Institute, Chinese Academy of Agricultural Sciences, 450009, Zhengzhou, Henan Province, People's Republic of China}

Additional index words. grapevine cultivars, SSR, microsatellite characterization, cultivar identification, Vitis

\begin{abstract}
In this study, we present the molecular characterization of 61 Chinese grape landraces and 33 foreign cultivars by using nine microsatellite DNA markers. A total of 115 distinct alleles were amplified, and the average allele number was 12.78 . The average observed and expected heterozygosity values were 0.797 and 0.839 , respectively. The effective allele numbers ranged from 5.011 to 8.575 . The average polymorphism information content (PIC) was 0.816 . Eighty distinct genotypes were detected, and new synonyms and homonyms were found. The clustering dendrogram indicated that 94 Vitis materials could be divided into five major groups, and the cluster analysis showed that part of the Chinese grape landraces had a close relationship with the foreign cultivars. Assessment of the true cultivar identity, and the identification of synonyms and homonyms will be a contribution to improve the grape germplasm management and protect breeders' intellectual rights.
\end{abstract}

The grape (Vitis L.), one of the most important fruit crops in the world, is grown in a wide range of environments (Liu et al., 2012). It is an important member of Vitaceae and has significant economic value. There are more than 70 species in the Vitis genus worldwide, and they are mainly found in the temperate regions of the Northern Hemisphere. The varieties mostly originated from three regions: Europe and western

\footnotetext{
Received for publication 24 Jan. 2017. Accepted for publication $21 \mathrm{Feb} .2017$.

This research was supported by the China Agriculture Research System (CARS-30) and the Agricultural Science and Technology Innovation Program (CAAS-ASTIP-2015-ZFRI) and was partially supported by the Cooperation Research on GenBank Collection Technology and Practices (2014DFG31860) and the National Basic Special Work Program of Science and Technology (2012FY11010015).

${ }^{1}$ These authors equally contributed to this work. ${ }^{2}$ Corresponding author. E-mail: liuchonghuai@ caas.cn.
}

Asia, North America, and eastern Asia (Alleweldt and Possingham, 1988; Kong, 2004; Mullins et al., 1992). Among these, Vitis vinifera L., which originates from Europe and west Asia, is the only species cultivated extensively around the world (This et al., 2006). About 6000-10,000 V. vinifera cultivars exist worldwide (Galet, 2000).

China has a long history of grape cultivation. Viticulture spread along the ancient Silk Road and it reached China in the second century AD (Nunez and Walker, 1989). In the midlate 19th century, the Catholic Church replaced the Romans in expanding grape cultivation (Royer, 1988). After the introduction of the grape into different locations in China, the original cultivar names were lost and they are still unknown today. Through long-term cultivation, many cultivars with excellent phenotypic traits were retained and regarded as local cultivars, and new names were given to these cultivars by local farmers. Therefore, many local grape cultivars exist in China. Currently, over 1400 grape accessions, including local cultivars from different sources, have been collected from China and overseas. Furthermore, these local cultivars have played a major role in breeding in China because of their rich morphological variation (Guo et al., 2012). Many new grape cultivars were bred with these local cultivars (Chang and Liu, 1993; Guo et al., 2012; Liu et al., 2002). Several local cultivars have also played key roles in promoting the development of the local economy. Cultivars such as the Guankouputao, one of the Geographical Indication Products in Jianshi County, Hubei Province, is highly accepted by the consumer (Giovannucci et al., 2009; Li et al., 2014). In recent years, with the continuous development of modern agriculture, growers abandoned the landrace varieties and instead switched to modern cultivars or recently bred cultivars. Therefore, many germplasm resources that were not preserved were lost permanently.

DNA molecular marker technique showing polymorphism at the DNA level is a powerful tool for the characterization of germplasms (Queiroz et al., 2015), the identification of cultivars (Gross et al., 2012; Semagn et al., 2006), and the estimation of genetic diversity (Mashilo et al., 2016; Parveen et al., 2016; Urrestarazu et al., 2015). Among the various DNA-based molecular markers, simple sequence repeats (SSRs), with the advantages of codominance inheritance, a high degree of polymorphism, reproducibility, and simple operation (Sefc et al., 2001), have been widely used in genetic diversity analyses of grape cultivars and the identification of germplasms (Emanuelli et al., 2013; Guo et al., 2010; Marinoni et al., 2009; This et al., 2004; Villano et al., 2014). Some countries have already used SSR markers to characterize grape collections, such as the United States (Adhikari et al., 2014), Hungary (Harangozó et al., 2013), Croatia (Maletić et al., 2015), Brazil (Leão et al., 2009), Slovenia (Stajner et al., 2011), Italy (Crespan et al., 2008), and France (Laucou et al., 2011).

However, only limited work has been published concerning Chinese grape landraces analyzed using SSR markers (Goto-Yamamoto et al., 2009; Guo et al., 2010). Most studies merely characterized several cultivars, and the genetic relationships among the landraces and introduced cultivars in China are not well known. Therefore, considerable effort should be exerted to characterize the genetic diversity among landraces and the introduced cultivars. In this study, we used a set of nine microsatellite markers recommended as the standard set for the screening of grapevine collections to characterize 61 Chinese grape landraces and 33 foreign cultivars (Mihaljevic et al., 2013). The aim of our study is to differentiate cultivars with similar morphological traits, and to better assess the genetic diversity and genetic relatedness among these landraces and introduced cultivars. The information obtained from our studies will be useful in the future 
Table 1. List of grape cultivars used in this study.

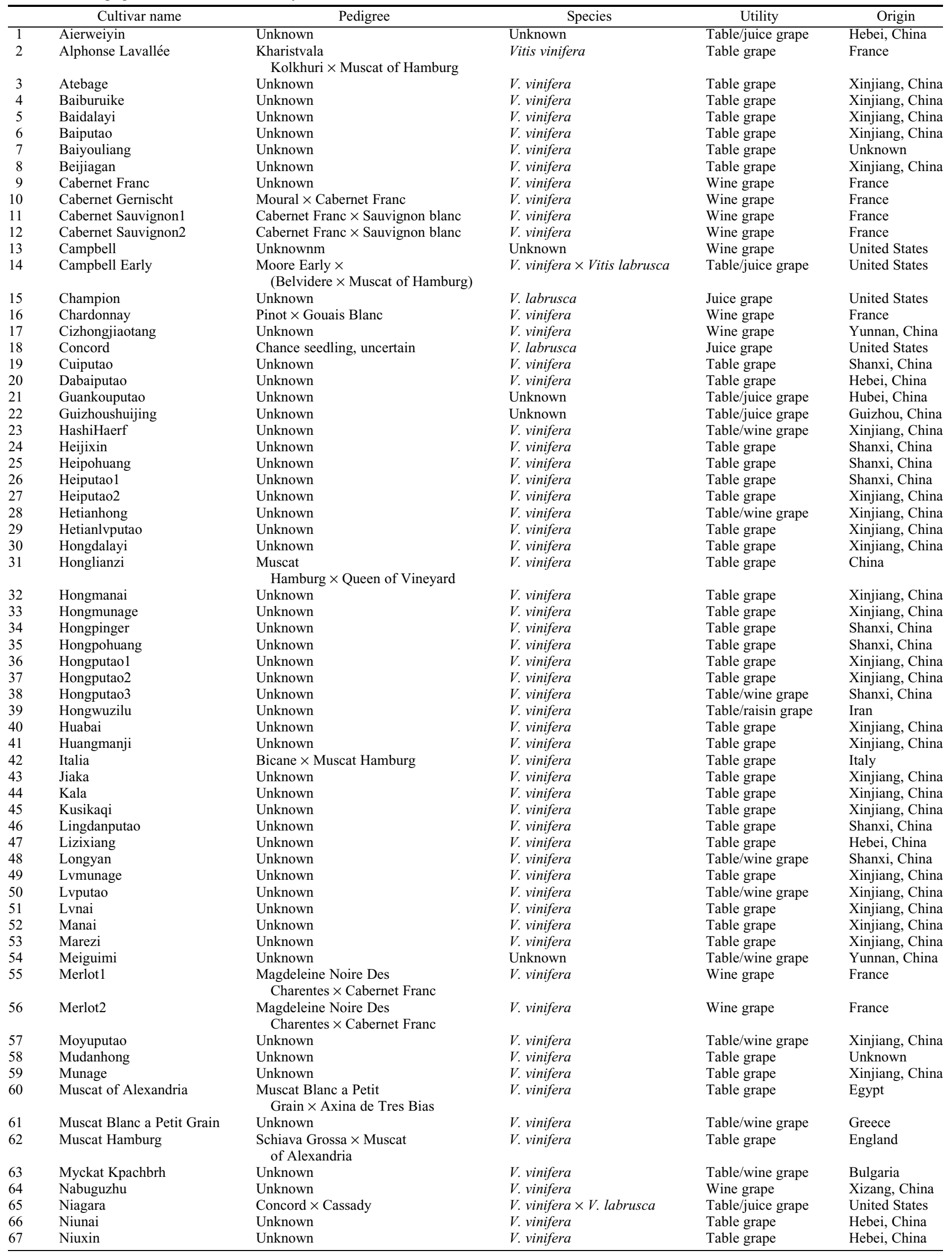


Table 1. (Continued) List of grape cultivars used in this study.

\begin{tabular}{|c|c|c|c|c|c|}
\hline & Cultivar name & Pedigree & Species & Utility & Origin \\
\hline$\overline{68}$ & Pannoniavinesa & Ivan $\times$ Logan & $V$. vinifera & Table grape & Hungary \\
\hline 70 & Pingdinghei & Unknown & $V$. vinifera & Table grape & Xinjiang, China \\
\hline 72 & Pinot Noir & Unknown & $V$. vinifera & Wine grape & France \\
\hline 73 & Qiaowushi & Unknown & $V$. vinifera & Table grape & Turkey \\
\hline 74 & Qiligan & Unknown & $V$. vinifera & Table grape & Xinjiang, China \\
\hline 77 & Suosuoputao & Unknown & V. vinifera & Raisin grape & Xinjiang, China \\
\hline 78 & Syrah & Unknown & V. vinifera & Wine grape & France \\
\hline 79 & Taokekeluke & Unknown & $V$. vinifera & Table grape & Xinjiang, China \\
\hline 80 & Thompson Seedless 1 & Unknown & $V$. vinifera & Table/raisin grape & Gongyi, China \\
\hline 81 & Thompson Seedless2 & Unknown & V. vinifera & Table/raisin grape & Ningxia, China \\
\hline 82 & Thompson Seedless3 & Unknown & $V$. vinifera & Table/raisin grape & Afghanistan \\
\hline 83 & Thompson Seedless4 & Unknown & V. vinifera & Table/raisin grape & West Asia \\
\hline 89 & Xiekelange & Unknown & V. vinifera & Table grape & Xinjiang, China \\
\hline 90 & Xiying & Unknown & $V$. vinifera & Table grape & Shanxi, China \\
\hline 91 & Yeliake & Unknown & $V$. vinifera & Table grape & Xinjiang, China \\
\hline 92 & Yilixiangputao & Unknown & V. vinifera & Table/wine grape & Xinjiang, China \\
\hline 93 & Yunnanshuijing & Unknown & Unknown & Table/raisin grape & Yunnan, China \\
\hline 94 & Zihongxingputao & Unknown & V. vinifera & Table grape & Xinjiang, China \\
\hline
\end{tabular}

The "origin" of the foreign cultivar refers to the geographical origin of that accession. The "origin" of the Chinese grape landrace refers to the region where it was collected.

breeding and management of these germplasm resources in ex situ conservation.

\section{Materials and Methods}

Plant materials and DNA extraction. Sixtyone local cultivars and 33 introduced cultivars were analyzed in this study (Table 1). These samples were collected from the National Grape Germplasm Repository of the Zhengzhou Fruit Research Institute of the Chinese Academy of Agricultural Sciences $\left(34^{\circ} 42^{\prime} 47.52^{\prime \prime} \mathrm{N}, 113^{\circ} 42^{\prime} 3.19^{\prime \prime} \mathrm{E}\right)$.

The genomic DNA was isolated from young leaves using a Plant Genomic DNA Kit (Tiangen Biotech, Beijing, China) according to the manufacturer's instructions. The DNA quality was checked by agarose gel electrophoresis analysis, and the DNA concentration and purity were determined using a NanoDrop 1000 spectrophotometer (NanoDrop, Wilmington, DE). Genomic DNA was normalized to $30-50 \mathrm{ng} / \mu \mathrm{L}$ and was stored at $-20^{\circ} \mathrm{C}$.

Polymerase chain reaction amplification and fragment sizing. For the characterization of grape landraces, the following nine SSR loci distributed on six chromosomes in the grape were used: VVMD5 and VVMD7 (Bowers et al., 1996); VVS2 (Thomas and Scott, 1993); VVMD 32, VVMD25, VVMD27, and VVMD28 (Bowers et al., 1999a); VrZAG62 and VrZAG79 (Sefc et al., 1999). These markers, each with high polymorphisms, were used by the European GrapeGen06 consortium (http://www1.montpellier.inra.fr/grapegen06/ accueil.php) and have been frequently used to identify cultivars (Mihaljevic et al., 2013; This et al., 2004).
The polymerase chain reaction (PCR) was performed in a $20-\mu \mathrm{L}$ volume containing $30-50$ ng of template DNA, $1 \times$ PCR buffer $\left(\mathrm{Mg}^{2+}\right.$ plus) (TaKaRa, Japan), $0.25 \mathrm{~mm}$ dNTPs, $0.5 \mu \mathrm{M}$ of each primer, and $1 \mathrm{U}$ of Taq DNA polymerase (TaKaRa, Japan). The forward primers were labeled with FAM or HEX fluorescent dye at the 5' -end. The PCR amplification was conducted in a Biometra TGradient Thermocycler (Biometra, Göttingen, Germany) and was performed according to the following thermal cycles: $4 \mathrm{~min}$ at $94{ }^{\circ} \mathrm{C}$ for initial denaturation, followed by 35 cycles of denaturation at $94{ }^{\circ} \mathrm{C}$ for $30 \mathrm{~s}$, annealing at optimum Ta for $30 \mathrm{~s}, 72^{\circ} \mathrm{C}$ for $45 \mathrm{~s}$ and a final extension at $72{ }^{\circ} \mathrm{C}$ for $10 \mathrm{~min}$, finally, the reaction was held at $4{ }^{\circ} \mathrm{C}$. PCR amplification products were separated by capillary electrophoresis in an ABI 3730xI DNA Analyser (Applied Biosystems, Carlsbad, CA). Raw data obtained by capillary electrophoresis were converted into allelic sizes using Gene Mapper v3.2 software (Applied Biosystems, Foster City, $\mathrm{CA}$ ), and fragment calibration was performed with an internal size standard (GeneScan500ROX; PE Applied Biosystems).

Data scoring and analysis. The microsatellite data were analyzed with the statistical software POPGENE version 1.32 (https://sites. ualberta.ca/ fyeh/popgene.html), and the number of alleles per locus $\left(\mathrm{N}_{\mathrm{a}}\right)$, number of effective alleles $\left(\mathrm{N}_{\mathrm{e}}\right)$, observed heterozygosity $\left(\mathrm{H}_{\mathrm{o}}\right)$, and expected heterozygosity $\left(\mathrm{H}_{\mathrm{e}}\right)$ were calculated. The PIC of each SSR was calculated using the following formula: $\mathrm{PIC}=1-\sum_{j=1}^{n} P i j^{2}$ (Botstein et al., 1980), where $P i j$ is the frequency of the $j$ th allele for the $i$ th SSR marker.

For statistical analysis, the amplified fragments were scored as either 1 (present) or
0 (absent) for each of the SSR markers. Then, the data were converted into a binary matrix and analyzed using the software package NTSYSpc 2.1 (Rohlf, 2000). The genetic similarity matrix based on the Dice coefficient of similarity was used to construct a dendrogram showing the approximate relationships among a set of accessions based on the unweighted pair group with arithmetic mean (UPGMA) method using the Mega-5.0 software (Tamura et al., 2011).

\section{Results and Discussion}

Microsatellite analysis. DNA from all of the samples was successfully amplified using each of the 9 SSRs, and 80 distinct genotypes were detected by analyzing 94 accessions (Table 2). A total of 115 alleles, with sizes between 121 and 289 base pairs, were obtained from 9 SSR primers (Table 2). The number of alleles per locus ranged from 10 alleles (VrZAG62) to 17 alleles (VVMD28), with an average of 12.78 alleles per locus (Table 3), which is higher than the findings obtained from some other national collections (Alba et al., 2015; Maletić et al., 2015; Stajner et al., 2011; Tomić et al., 2012) but is in accordance with the results of the southern Italy collections (Villano et al., 2014). This difference is due to the increased existence of low-frequency alleles in large-scale sample sets (Laiadi et al., 2009).

In this study, the percentage of heterozygotes of the nine loci was high, indicating the high variability present in the samples. The expected heterozygosity values ranged from 0.805 at locus VVMD32 to 0.888 at locus VVS2, the average value of the expected 
Table 2. Genetic profiles of 64 grape landraces and 30 introduced cultivars at 9 microsatellite loci.

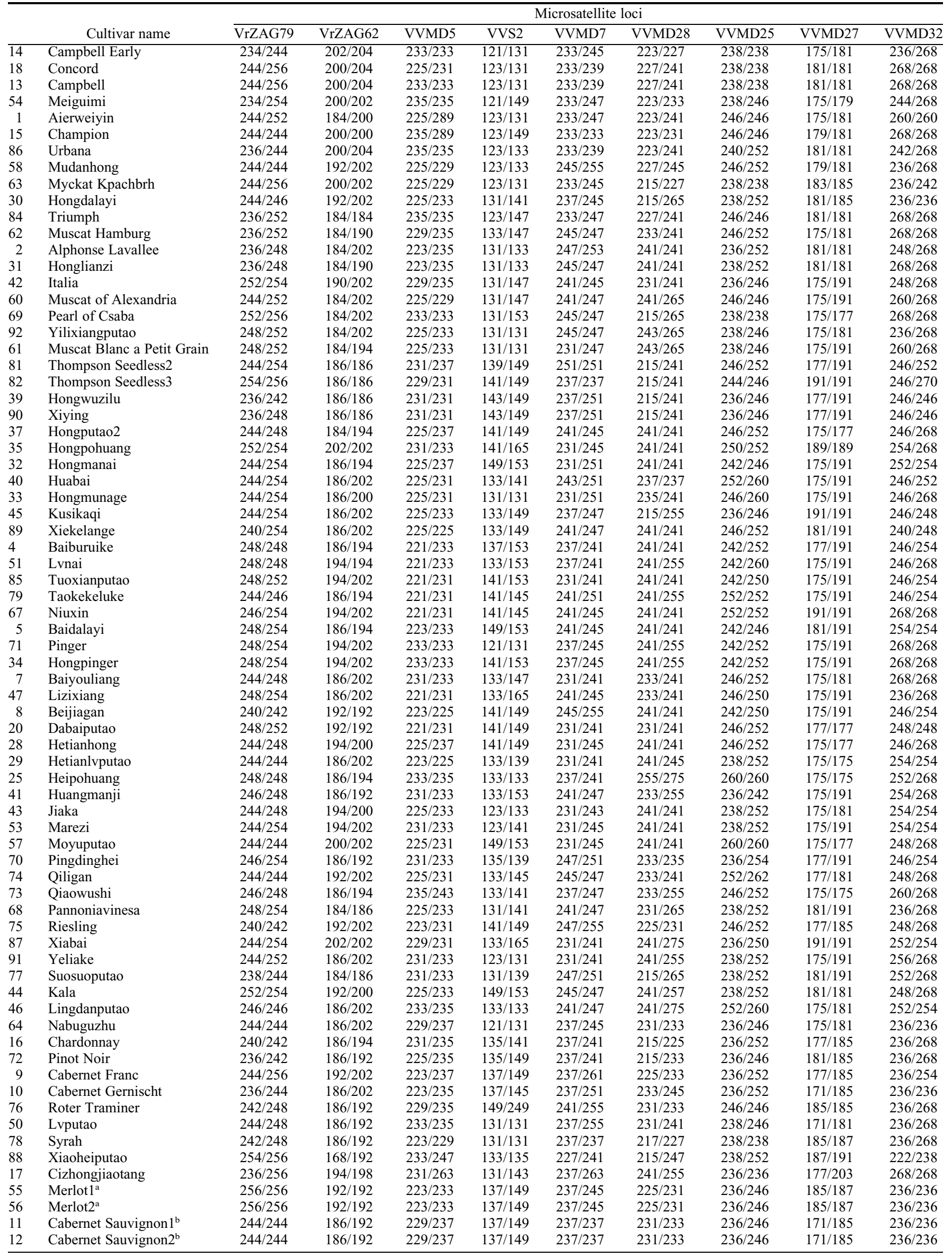

(Continued on next page) 
Table 2. (Continued) Genetic profiles of 64 grape landraces and 30 introduced cultivars at 9 microsatellite loci.

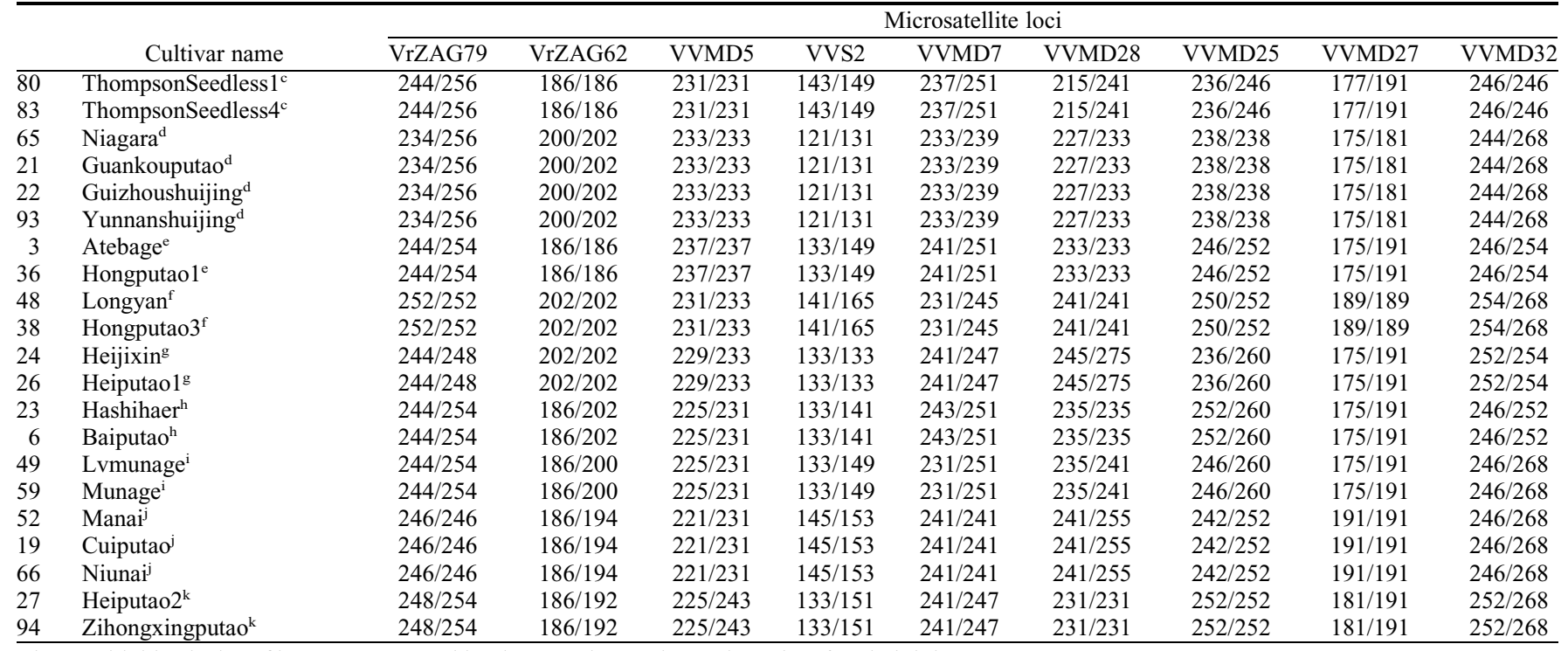

Clones with identical profiles are represented by the same letters, i.e., a, b, c, d, e, f, g, h, i, j, k.

Table 3. Number of alleles (Na), effective number of alleles $(\mathrm{Ne})$, observed $\left(\mathrm{H}_{\mathrm{o}}\right)$ and expected $\left(\mathrm{H}_{\mathrm{e}}\right)$ heterozygosity, and polymorphism information content (PIC) of the nine simple sequence repeat loci analyzed.

\begin{tabular}{llcccc}
\hline Locus & $\mathrm{Na}$ & $\mathrm{Ne}$ & $\mathrm{H}_{\mathrm{o}}$ & $\mathrm{H}_{\mathrm{e}}$ & $\mathrm{PIC}$ \\
\hline VrZAG79 & 11 & 6.449 & 0.811 & 0.849 & 0.828 \\
VrZAG62 & 10 & 5.250 & 0.768 & 0.814 & 0.784 \\
VVS2 & 15 & 8.575 & 0.884 & 0.888 & 0.873 \\
VVMD5 & 12 & 6.631 & 0.811 & 0.854 & 0.832 \\
VVMD7 & 14 & 7.920 & 0.905 & 0.878 & 0.861 \\
VVMD28 & 17 & 5.635 & 0.747 & 0.827 & 0.810 \\
VVMD25 & 11 & 5.486 & 0.768 & 0.822 & 0.793 \\
VVMD32 & 14 & 5.011 & 0.695 & 0.805 & 0.778 \\
VVMD27 & 11 & 5.176 & 0.779 & 0.811 & 0.780 \\
Mean & 12.78 & 6.237 & 0.797 & 0.839 & 0.815 \\
\hline
\end{tabular}

heterozygosity is 0.839 , which was higher than that reported by Carimi et al. (2010) (0.791) among Sicilian grapevine cultivars. The values of observed heterozygosity for individual loci ranged from 0.695 at locus VVMD32 to 0.905 at locus VVMD7, with a mean of 0.797 (Table 3). The mean expected heterozygosity was slightly higher than the observed heterozygosity. This difference could be explained by the lack of both natural and human selection, which reduced homozygosity in grape plants (Sefc et al., 2001).

The values of PIC varied from 0.778 to 0.873 , with a mean of 0.815 . The most informative locus was VVS2 (0.873) and the least informative locus was VVMD32 (0.778) (Table 3). The mean PIC value was higher than that reported by Ramezani et al. (2009) $(0.77)$ in grape, the high PIC value suggesting a high discriminating ability of the SSR markers for the grape landraces.

Duplicates and homonyms. Of the 94 cultivars analyzed in this study, the identities of several duplicates from different provenances were confirmed (Table 2), namely for Thompson seedless (Thompson Seedless1 and
Thompson Seedless4), Cabernet Sauvignon (Cabernet Sauvignon1 and Cabernet Sauvignon2), and Merlot (Merlot1 and Merlot2). Further research will be needed to establish the trueness-to-type of these cultivars.

Several homonyms, particularly Thompson Seedless (Thompson Seedless1, Thompson Seedless2, and Thompson Seedless3), Hongputao (Hongputao1, Hongputao2, and Hongputao3), Campbell and Campbell Early, and Heiputao (Heiputao1 and Heiputao2) (Table 2), were identified. The three clones of Thompson Seedless were grown in different locations (Table 1). Thompson Seedless 1 and Thompson Seedless4 are the true Thompson Seedless (www.vivc.de). Thompson Seedless2 and Thompson Seedless3 shared identical genotypes at three loci (VrZAG62, VVMD27, and VVMD28) with Thompson Seedless1, but they had at least one allele at each locus in common, which could mean a parent-offspring relationship between them. Besides, the maturity of Thompson Seedless 2 and Thompson Seedless 3 is earlier than Thompson Seedless1, and the fecundity of Thompson Seedless2 and Thompson Seedless3 is better than that of Thompson Seedless1. Additionally, the clones of Hongputao and Heiputao all showed different microsatellite profiles in at least eight SSR loci analyzed. Among these, Hongputaol and Hongputao2 both came from Xinjiang, and Hongputao3 came from Shanxi, whereas Heiputao1 came from Shanxi, and Heiputao2 came from Xinjiang. However, according to the record, only Hongputao1 and Heiputao2 were the real local cultivars of Xinjiang (Kong, 2004), whereas the other cultivars, named Hongputao and Heiputao, were likely misnamed by local farmers in the 19th century according to the berries' skin color. It is reported that Campbell and Campbell Early are the same cultivar (www.vivc.de), whereas in our study, they did not share the same genetic profile. It might be that there was an error in the progress of germplasm transmission.

Synonyms. There were also cases of synonyms among samples with different names but identical SSR profiles at all nine analyzed loci, such as Guizhoushuijing, Yunnanshuijing, Guankouputao, and Niagara; Longyan and Hongputao3; Heijixin and Heiputao1; Lvmunage and Munage; Atebage and Hongputao1; Manai, Niunai, and Cuiputao; Hashihaer and Baiputao; and Heiputao2 and Zihongxingputao.

Niagara, obtained by cross-breeding in 1868 , is native to the United States. It was imported into Japan in 1883 and was cultivated in the Hokkaido and Nagano areas. When and how Niagara was introduced into China is still unclear. Niagara was sporadically cultivated in the church of Hohhot, Inner Mongolia of China, in the 1940s (Kong, 2004). Meanwhile, Guizhoushuijing, Yunnanshuijing, and Guankouputao have been collected from Guizhou, Yunnan, and Hubei, respectively. All three have similar morphological characteristics to Niagara: the young shoot is green-yellow in color, the tender leaf is grey-green, the mature leaf is dark green, the berry skin color is chartreuse, the berry shape is near round, and the flesh has an intense strawberry fragrance with a soft texture and high juice content. Our results showed that the four cultivars have the same genotype. Guankouputao, Yunnanshuijing, and Guizhoushuijing could be local names for Niagara. The results were similar to those reported by Li et al. (2014), who analyzed the genetic relationship of Guankouputao grapes using SSR and IRAP markers. For Longyan and Hongputao3, Heijixin and Heiputao1, the four cultivars were all collected from Qingxu, Shanxi. Longyan and Heijixin belong to a class of Oriental cultivars and are important ancient Chinese cultivars (Guo et al., 2010). According to the skin color of Longyan and 


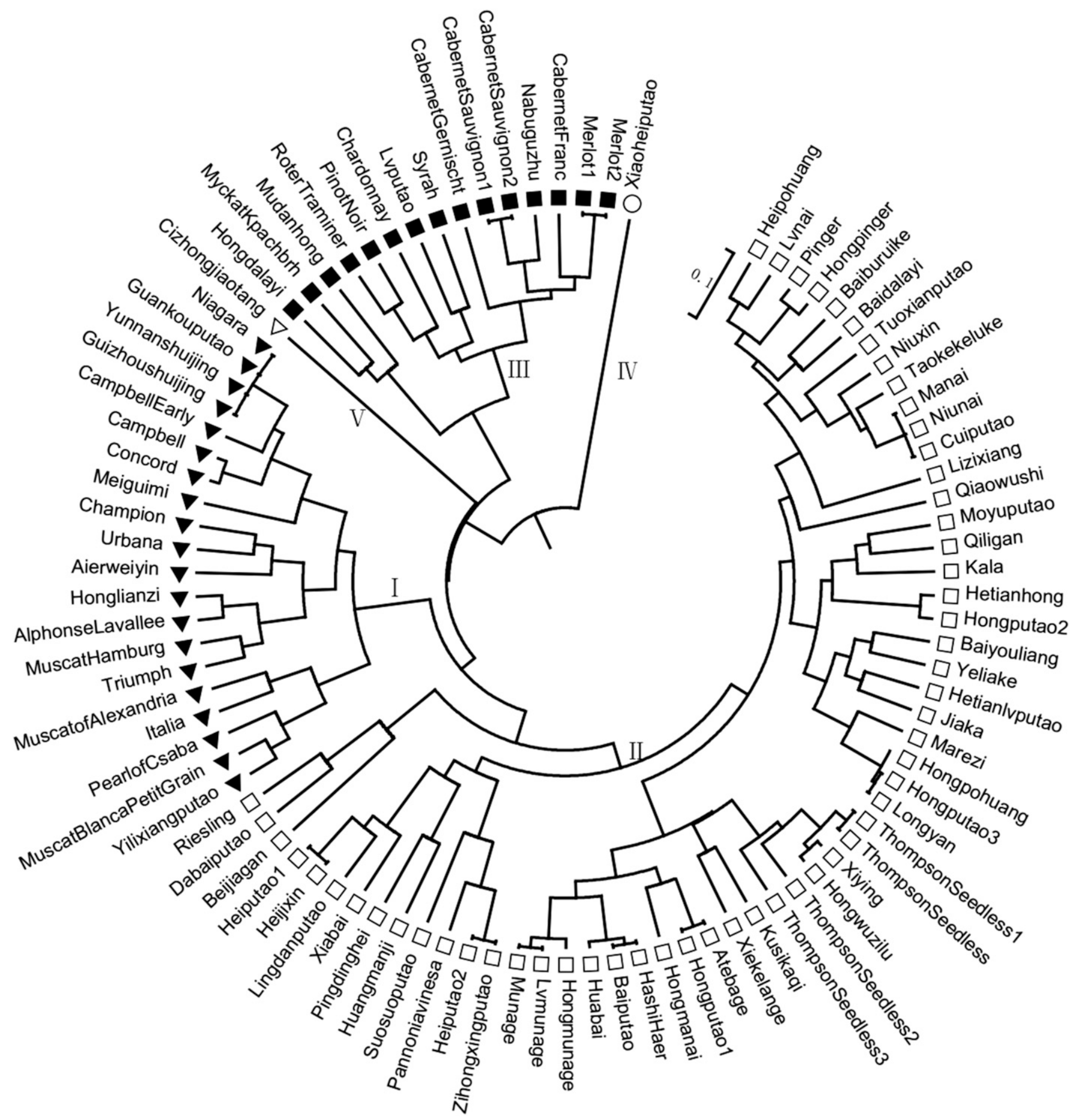

Fig. 1. Dendrogram of genetic similarities based on nine simple sequence repeat loci of 94 genotypes by means of the Dice coefficient. The cultivars labeled with the same symbol are a group.

Heijixin, Heijixin also had another name, Heiputao; Longyan was also called Hongputao by the local people in Qingxu, Shanxi Province (Jin and Yang, 1982). In this study, Heijixin and Heiputao1, Longyan and Hongputao3 are actually the same variety. Similar cases also exist between Lvmunage and Munage and between Atebage and Hongputao1; all four accessions were from Xinjiang. The Uyghur names of Lvmunage and Hongputaol are Munage and Atebage, respectively. In addition, Niunai, Manai, and
Cuiputao are also the same variety grown in different locations. Niunai was called Manai in Xinjiang and was also called Cuiputao in Shanxi (Kong, 2004). Hashihaer was collected from Xinjiang and was called Baiputao; they belonged to the same variety as well (Kong, 2004). Heiputao 2 and Zihongxingputao were from Xinjiang and share the same genetic profile. Therefore, Zihongxingputao could be a local name for Heiputao. Similar synonyms often appear in apple (Gross et al., 2012) and pear (Cheng and Huang, 2009).
Furthermore, we also compared the Chinese accessions' genotype with the Vitis International Variety Catalogue database (www.vivc.de). We found that five Chinese accessions shared the same genetic profile with foreign cultivars: Hetianhong and KuldzhinskII; Kusikaqi and Emerald seedless; Lvmunage and Gissary; Campbell and Eaton; Cizhongjiaotang and Baco noir; Yilixiangputao and Muscat fleur d' oranger. So they might be the same cultivar. Especially for Hetianhong and KuldzhinskII, it 
has been proved that they are synonyms (http://www.vivc.de/index.php? $\mathrm{r}=$ passport $\%$ 2Fview\&id=6548). In addition, we also found that Kala and Foster's White Seedling only mismatch at one locus (VrZAG79). We guess that variations might have occurred in Kala after Foster's White Seedling's arrival and settlement in China. As Milla-Tapia et al. (2013) reported that to adapt to particular environments, genetic variations might occur in grapevines. Further research is still needed. Finally, the identification of these homonyms and synonyms will help us to clearly identify germplasm sources and will contribute to the use of germplasms.

Genetic relatedness based on the cluster analysis. A dendrogram was constructed based on the matrix of the genetic distances using UPGMA clustering analysis. The grape accessions studied were distinctly classified into five major clusters (Fig. 1). Xiaoheiputao and Cizhongjiaotang separated from the other cultivars, forming two individual groups, namely, groups IV and V. Group I included all of the cultivars with foxy or muscat flavor. Group II consisted of most of the ancient Chinese accessions related to Oriental cultivars. Group III included most of the introduced cultivars.

Group I consisted of 20 cultivars and included all of the cultivars with foxy or muscat flavor (Fig. 1). In this group, samples related to Muscat Hamburg were grouped together, and samples with Concord in their pedigrees, such as Campbell Early, Niagara, and Campbell, were closely clustered. Some accessions with parent relationships were clustered together, such as Honglianzi and Alphonse Lavallee (both are offspring of Muscat Hamburg). Muscat of Alexandria clustered closely with one of its parents, Muscat Blanc a Petits grains (Cipriani et al., 2010).

In this group, Campbell shares the same genotype with Eaton which originated from United States (www.vivc.de). So we guess that they may be the same cultivar. Campbell and Concord mismatched at one locus (VVMD5) and clustered together, suggesting that Campbell may be a mutation of Concord (Einset and Lamb, 1951). Yilixiangputao from Xinjiang shares a common set of alleles with Muscat Blanc a Petit Grain, suggesting that these cultivars could have a familial connection. Meanwhile, we speculate that Yilixiangputao and Muscat fleur d' oranger may be the same cultivar with same genetic profile, and Muscat Blanc a Petit Grain is one of the parents of Muscat fleur d' oranger (Schneider et al., 2008). So Muscat Blanc a Petit Grain also may be one of the parents of Yilixiangputao.

Group II consisted of 57 cultivars and was the largest and most complex group. Most ancient Chinese accessions are in this cluster. For example, Longyan, Hongputao, Niunai, Pinger, Lizixiang, Niuxin, and Heijixin belonged to Oriental cultivars (Fig. 1). In this group, six seedless cultivars were grouped together, including Thompson Seedless4, Thompson Seedless1, Hongwuzilu, Xiying, Thompson Seedless2, and Thompson Seedless3.
The cluster analysis results were in agreement with Guo et al. (2010), who studied the genetic diversity and relationships among Chinese and European/American grape cultivars using SSRs.

Xiying came from Shanxi Qingxu, and Hongwuzilu originated from Iran. These two accessions are near synonyms, only mismatched at one locus (VrZAG79), revealing their close genetic relatedness and indicating a possible familial connection. Liu et al. (2006) investigated the morphological characteristics of 37 seedless grape cultivars in the National Zhengzhou Grape Germplasm Resources Repository and reported similar results. Longyan and Hongpohuang also mismatched at one locus (VrZAG79) and clustered together, reflecting the close genetic relationship between them. We guess that Longyan and Hongpohuang is probably the case of a near synonym. A similar case also exists between Hongputao2 and Hetianhong, a widely cultivar well known in China since the 19th century. It is reported that the groups of near synonyms are probably to be a mix of clones (Cipriani et al., 2010; Lefort and Roubelakis-Angelakis, 2001).

The foreign cultivars Syrah, Myckat Kpachbrh, Mudanhong, Cabernet Sauvignon1, Cabernet Sauvignon2, Chardonnay, Roter Traminer, Pinot Noir, Cabernet Gernischt, Merlot1, Merlot2, and Cabernet Franc were clustered with three Chinese local grapevines, Lvputao, Hongdalayi, and Nabuguzhu, to form group III (Fig. 1). This result indicates that they likely have a close genetic relationship with each other. In addition, in this group, some accessions with close genetic relationships are grouped closely; e.g., the cultivars Pinot Noir and Chardonnay cluster closely (Bowers et al., 1999b). Additionally, progenies are also grouped close to one of their parents, such as Cabernet Sauvignon and Cabernet Franc (Bowers and Meredith, 1996).

In group III, Hongdalayi collected from Xinjiang and Myckat Kpachbrh originated from Bulgaria share $50 \%$ of alleles, exactly one allele at each analyzed locus, and they could have a parent-offspring relationship (Tomić et al., 2012). Nabuguzhu was collected from Xizang, and its SSR profiles were compared with those of Cabernet Sauvignon from France. Despite the two primers (VVS2, VVMD27), they have at least one allele at each analyzed locus in common, suggesting a close relationship between them. Further research will be needed to explore its true identity.

Xiaoheiputao, namely Suxiaohong, is an old local variety from Suqian City of Jiangsu Province. Huang and Sheng (1993) reported that Suxiaohong had a close relationship with $V$. pseudoreticulata, a unique Chinese wild grape. Cizhongjiaotang from Yunnan Province is an ancient grape cultivar that has been cultivated in churches built by French missionaries in Yunnan. Furthermore, Cizhongjiaotang shares the same genotype with Baco noir which originated from France, so we speculated that Cizhongjiaotang could originate from France.
The results of clustering revealed that the origins of some Chinese local cultivars might be related to foreign cultivars. While most Chinese local cultivars are genetically separated from foreign cultivars to form a group, this separation might be the result of longterm domestication or might be the result of a lack of reference varieties. Further research is still needed.

\section{Conclusions}

The analysis of 94 grape accessions from China and abroad revealed 80 distinct genotypes. Some homonyms and synonyms were found, such as Hongputaol and Hongputao2; Lvmunage and Munage; Hashihaer and Baiputao; Hetianhong and KuldzhinskII; Kusikaqi and Emerald seedless, and so on. The results of the present work suggest that the Chinese grape landraces have a close relationship with the foreign cultivars. Our work will contribute to the effective management of germplasm repositories and the protection of breeders' rights. Meanwhile, we advise that the management of local accessions should be standardized.

\section{Literature Cited}

Adhikari, P., L. Chen, X. Chen, S.D. Sapkota, and C. Hwang. 2014. Interspecific hybrid identification of Vitis aestivalis-derived 'Norton'-based populations using microsatellite markers. Scientia Hort. 179:363-366.

Alba, V., C. Bergamini, R. Genghi, M. Gasparro, R. Perniola, and D. Antonacci. 2015. Ampelometric leaf trait and SSR loci selection for a multivariate statistical approach in Vitis vinifera $\mathrm{L}$. biodiversity management. Mol. Biotechnol. 57:709-719.

Alleweldt, G. and J.V. Possingham. 1988. Progress in grapevine breeding. Theor. Appl. Genet. 75:669-673.

Botstein, D., R.L. White, M. Skolnick, and R.W Davis. 1980. Construction of a genetic linkage map in man using restriction fragment length polymorphisms. Amer. J. Hum. Genet. 32:314-331.

Bowers, J., J.M. Boursiquot, P. This, K. Chu, H. Johansson, and C. Meredith. 1999a. Historical genetics: The parentage of Chardonnay, Gamay, and other wine grapes of northeastern France. Science 285:1562-1565.

Bowers, J.E., G.S. Dangl, and C.P. Meredith. 1999b. Development and characterization of additional microsatellite DNA markers for grape. Amer. J. Enol. Viticult. 50:243-246.

Bowers, J.E., G.S. Dangl, R. Vignani, and C.P. Meredith. 1996. Isolation and characterization of new polymorphic simple sequence repeat loci in grape (Vitis vinifera L.). Genome 39:628-633.

Bowers, J.E. and C. Meredith. 1996. Genetic similarities among wine grape cultivars revealed by restriction fragment-length polymorphism (RFLP) analysis. J. Amer. Soc. Hort. Sci. 121:620-624.

Carimi, F., F. Mercati, L. Abbate, and F. Sunseri. 2010. Microsatellite analyses for evaluation of genetic diversity among Sicilian grapevine cultivars. Genet. Resources Crop Evol. 57:703-719.

Chang, Y.J. and H.B. Liu. 1993. Local speciesZexiang. China Fruits 3:030 (in Chinese).

Cheng, Z. and H. Huang. 2009. SSR fingerprinting Chinese peach cultivars and landraces (Prunus 
persica) and analysis of their genetic relationships. Scientia Hort. 120:188-193.

Cipriani, G., A. Spadotto, I. Jurman, G. Di Gaspero, M. Crespan, S. Meneghetti, E. Frare, R. Vignani, M. Cresti, M. Morgante, M. Pezzotti, E. Pe, A. Policriti, and R. Testolin. 2010. The SSR-based molecular profile of 1005 grapevine (Vitis vinifera $\mathrm{L}$.) accessions uncovers new synonymy and parentages, and reveals a large admixture amongst varieties of different geographic origin. Theor. Appl. Genet. 121:1569-1585.

Crespan, M., A. Calo, S. Giannetto, A. Sparacio, P. Storchi, and A. Costacurta. 2008. 'Sangiovese' and 'Garganega' are two key varieties of the Italian grapevine assortment evolution. Vitis 47:97-104.

Einset, J. and B. Lamb. 1951. Chimeral sports of grapes: Alleged tetraploid varieties have diploid "skin." J. Hered. 42:159-162.

Emanuelli, F., S. Lorenzi, L. Grzeskowiak, V. Catalano, M. Stefanini, M. Troggio, S. Myles, J.M. Martinez-Zapater, E. Zyprian, F.M. Moreira, and M.S. Grando. 2013. Genetic diversity and population structure assessed by SSR and SNP markers in a large germplasm collection of grape. BMC Plant Biol. 13:1-17.

Galet, P. 2000. Dictionnaire encyclopédique des cepages. Hachette Livre, Paris, France.

Giovannucci, D., T.E. Josling, W. Kerr, B. O’Connor, and M.T. Yeung. 2009. Guide to geographical indications: Linking products and their origins (Summary). MPRA Paper. International Trade Centre, Geneva, Switzerland.

Goto-Yamamoto, N., M. Numata, G. Wan, T. Shimamoto, and K. Hashizume. 2009. Characterization of oriental cultivars of grapevine using a reference allele system of microsatellite data and assignment test. J. Jpn. Soc. Hort. Sci. 78:175-179.

Gross, B.L., G.M. Volk, C.M. Richards, P.L. Forsline, G. Fazio, and C.T. Chao. 2012. Identification of "duplicate" accessions within the USDA-ARS National Plant Germplasm System Malus collection. J. Amer. Soc. Hort. Sci. 137:333-342.

Guo, D.L., J.Y. Zhang, and C.H. Liu. 2012. Genetic diversity in some grape varieties revealed by SCoT analyses. Mol. Biol. Rpt. 39:5307-5313.

Guo, D.L., J.Y. Zhang, C.H. Liu, G.H. Zhang, and M. Li. 2010. Genetic relationships of Chinese grape accessions to European and American cultivars assessed by microsatellite markers. Biotechnol. Equip. 24:2054-2059.

Harangozó, T., G. Pernesz, A. Veres, K. TothLencses, L. Heszky, and E. Kiss. 2013. Assessment of morphological and molecular similarity of Hungarian white grape varieties. Acta Biol. Hung. 64:231-248.

Huang, F. and B.C. Sheng. 1993. Study on the relationship between Suxiaohong grape and some species of Vitis. J. Nanjing Agr. Univ. 16:49-54 (in Chinese).

Jin, D.W. and R.S. Yang. 1982. Qingxu grape. Shanxi Fruits 1:037 (in Chinese).

Kong, Q.S. 2004. Flora of Chinese grapes. China Agriculture and Technology Press, Beijing, China (in Chinese).

Laiadi, Z., M.M. Bentchikou, G. Bravo, F. Cabello, and J.M. Martínez-Zapater. 2009. Molecular identification and genetic relationships of Algerian grapevine cultivars maintained at the germplasm collection of Skikda (Algeria). Vitis 48:25-32.

Laucou, V., T. Lacombe, F. Dechesne, R. Siret, J. P. Bruno, M. Dessup, T. Dessup, P. Ortigosa,
P. Parra, C. Roux, S. Santoni, D. Vares, J.P. Peros, J.M. Boursiquot, and P. This. 2011. High throughput analysis of grape genetic diversity as a tool for germplasm collection management. Theor. Appl. Genet. 122:1233-1245.

Leão, P.C., S. Riaz, R. Graziani, G.S. Dangl, S.Y. Motoike, and M.A. Walker. 2009. Characterization of a Brazilian grape germplasm collection using microsatellite markers. Amer. J. Enol. Viticult. 60:517-524.

Lefort, F. and K.K. Roubelakis-Angelakis. 2001. Genetic comparison of Greek cultivars of Vitis vinifera $\mathrm{L}$. by nuclear microsatellite profiling. Amer. J. Enol. Viticult. 52:101-108.

Li, H., Z.R. Luo, and Q.L. Zhang. 2014. Genetic relationship analysis of 'Guankou-putao' grape by SSR and IRAP markers. Guoshu Xuebao 31:1040-1046. (in Chinese).

Liu, C.H., X.C. Fan, J.F. Jiang, D.L. Guo, H.S. Sun, Y. Zhang, and J.G. Feng. 2012. Genetic diversity of Chinese wild grape species by SSR and SRAP markers. Biotechnol. Equip. 26:2899-2903.

Liu, C.H., Q.S. Kong, and X. Pan. 2002. Germplasm background of the grape varieties bred in China and its innovation. Guoshu Xuebao 19:256-261. (in Chinese)

Liu, C.H., F. Tie, X. Pan, J.N. Guo, and X.C. Fan. 2006. Cluster analysis of seedless grape cultivars. Guoshu Xuebao 23:531-533. (in Chinese).

Maletić, E., I. Pejic, J.K. Kontić, D. Zdunić, D. Preiner, S. Simon, and D. Stupic. 2015. Ampelographic and genetic characterization of Croatian grapevine varieties. Vitis 54:93-98.

Marinoni, D.T., S. Raimondi, P. Ruffa, T Lacombe, and A. Schneider. 2009. Identification of grape cultivars from Liguria (northwestern Italy). Vitis 48:175-183.

Mashilo, J., H. Shimelis, A. Odindo, and B Amelework. 2016. Genetic diversity of South African bottle gourd [Lagenaria siceraria (Molina) Standl.] landraces revealed by simple sequence repeat markers. HortScience 51:120 126.

Mihaljevic, M.Z., S. Simon, I. Pejic, F. Carka, R. Sevo, A. Kojic, and D. Preiner. 2013. Molecular characterization of old local grapevine varieties from south east European countries. Vitis 52:69-76.

Milla-Tapia, A., S. Gomez, X. Moncada, P. Leon, A. Ibacache, M. Rosas, and A. Zurita-Silva 2013. Naturalised grapevines collected from arid regions in northern Chile exhibit a high level of genetic diversity. Austral. J. Grape Wine Res. 19:299-310.

Mullins, M.G., A. Bouquet, and L.E. Williams. 1992. Biology of the grapevine. Cambridge University Press, New York.

Nunez, D.R. and M.J. Walker. 1989. A review of palaeobotanical findings of early Vitis in the Mediterranean and of the origins of cultivated grape-vines, with special reference to new pointers to prehistoric exploitation in the western Mediterranean. Rev. Palaeobot. Palynol. 61:205-237.

Parveen, S., A. Shahzad, and V. Yadav. 2016. Molecular markers and their application in plant biotechnology, p. 389-413. In: A. Shahzad, S. Sharma, and S.A. Siddiqui (eds.). Biotechnological strategies for the conservation of medicinal and ornamental climbers Springer International Publishing, Cham, Switzerland.

Queiroz, A., A. Assunção, I. Ramadas, W. Viegas, and M.M. Veloso. 2015. Molecular characterization of Portuguese pear landraces (Pyrus communis L.) using SSR markers. Scientia Hort. 183:72-76.

Ramezani, A., R. Haddad, M. Dorostkar, M. Mardi, and M. Naghavi. 2009. Evaluation of genetic diversity of Iranian grapevine accessions using microsatellite markers. Vitis 48:151-152.

Rohlf, J.F. 2000. NTSYSpc numerical taxonomy and multivariate analysis system. Version 2.1. Exeter Software, Setauket, NY.

Royer, C. 1988. Mouvement historiques de la vigen dans le monde, p. 15-25. In: La Vigne et le Vin. Graficas, Lyon, France.

Schneider, A., D.T. Marinoni, and M. Crespan. 2008. Genetics and ampelography trace the origin of Muscat fleur d'oranger. Amer. J. Enol. Viticult. 59:200-204.

Sefc, K.M., F. Lefort, M.S. Grando, K.D. Scott, H. Steinkellner, and M.R. Thomas. 2001. Microsatellite markers for grapevine: A state of the art, p. 433-463. In: K.A. Roubelakis-Angelakis (ed.). Molecular biology \& biotechnology of the grapevine. Springer Netherlands, Dordrecht, the Netherlands.

Sefc, K.M., F. Regner, E. Turetschek, J. Glossl, and H. Steinkellner. 1999. Identification of microsatellite sequences in Vitis riparia and their applicability for genotyping of different Vitis species. Genome 42:367-373.

Semagn, K., A. Bjørnstad, and M.N. Ndjiondjop. 2006. An overview of molecular marker methods for plants. Afr. J. Biotechnol. 5:2540-2568.

Stajner, N., D. Rusjan, Z. Korosec-Koruza, and B. Javornik. 2011. Genetic characterization of old Slovenian grapevine varieties of Vitis vinifera L. by microsatellite genotyping. Amer. J. Enol. Viticult. 62:250-255.

Tamura, K., D. Peterson, N. Peterson, G. Stecher, M. Nei, and S. Kumar. 2011. MEGA5: Molecular evolutionary genetics analysis using maximum likelihood, evolutionary distance, and maximum parsimony methods. Mol. Biol. Evol. 28:2731-2739.

This, P., A. Jung, P. Boccacci, J. Borrego, R. Botta, L. Costantini, M. Crespan, G.S. Dangl, C. Eisenheld, F. Ferreira-Monteiro, S. Grando, J. Ibanez, T. Lacombe, V. Laucou, R. Magalhaes, C.P. Meredith, N. Milani, E. Peterlunger, F. Regner, L. Zulini, and E. Maul. 2004. Development of a standard set of microsatellite reference alleles for identification of grape cultivars. Theor. Appl. Genet. 109:1448-1458.

This, P., T. Lacombe, and M.R. Thomas. 2006. Historical origins and genetic diversity of wine grapes. Trends Genet. 22:511-519.

Thomas, M.R. and N.S. Scott. 1993. Microsatellite repeats in grapevine reveal DNA polymorphisms when analysed as sequencetagged sites (STSs). Theor. Appl. Genet. 86: 985-990.

Tomić, L., N. Stajner, T. Jovanovic-Cvetkovic, M. Cvetkovic, and B. Javornik. 2012. Identity and genetic relatedness of Bosnia and Herzegovina grapevine germplasm. Scientia Hort. 143:122-126.

Urrestarazu, J., C. Miranda, L.G. Santesteban, and J.B. Royo. 2015. Recovery and identification of grapevine varieties cultivated in old vineyards from Navarre (northeastern Spain). Scientia Hort. 191:65-73.

Villano, C., D. Carputo, L. Frusciante, X. Santoro, and R. Aversano. 2014. Use of SSR and retrotransposon-based markers to interpret the population structure of native grapevines from southern Italy. Mol. Biotechnol. 56:10111020 . 